\title{
PHYSIOLOGICAL ASPECTS OF NITROGEN FERTILIZER IMPACT ON LATVIAN ORIGIN CANNABIS SATIVA L.
}

\author{
Marija Mal̦ceva $^{1,2}$, Veneranda Stramkale ${ }^{2}$, Māra Vikmane ${ }^{1}$ \\ 1- Department of Plant Physiology, Faculty of Biology, University of Latvia \\ Kronvalda Bulv. 4, Riga, LV 1586, Latvia \\ 2- Agricultural Science Centre of Latgale, Kulturas Sq. 1, Vilani, LV 4650, Latvia \\ E-mail: marija_malceva@inbox.lv
}

\begin{abstract}
The aim of the present study was to evaluate nitrogen fertilizer impact on photosynthesis and yield of hemp, applying modern non-destructive methods. The main object of the investigation - hemp cultivar of Latvian origin 'Pürini'. Laboratory and field experiments showed diverse effects of different nitrogen fertilizer doses on various parameters. Additional nitrogen fertilizer dose of $60 \mathrm{~kg} \mathrm{ha}^{-1}$ is most effective as evaluated by chlorophyll content in hemp leaves and changes of chlorophyll a fluorescence parameters. Nitrogen fertilizer negatively affected fiber content in hemp stems, therefore while cultivating hemp only for fiber production use of nitrogen fertilizer should be reduced. According to the seed mass results, additional nitrogen fertilizer doses should be applied following the climatic conditions. In the vegetation period guided with higher rainfall levels, $60 \mathrm{~kg}$ of additional nitrogen fertilizer per hectare can be considered as optimal amount. In current investigation hempseed oil composition was not negatively affected by nitrogen fertilizer. Also significant difference between seed yield of $N_{60}$ and $N_{100}$ variants has not been observed. To avoid excessive nitrogen fertilizer usage, its negative impact on plant physiology and yield losses, we consider nitrogen fertilizer $60 \mathrm{~kg} \mathrm{ha}^{-1}$ as additional fertilizer is optimal for hemp cultivar 'Pūriņi'.
\end{abstract}

Key words: Cannabis sativa L., nitrogen fertilizer, chlorophyll content, chlorophyll a fluorescence, yield.

\section{Introduction}

All over the World hemp has both economic and pharmaceutical value [1], and is commercially cultivated in Europe, China, Japan and USA [2]. Minimal quantities or no herbicides, pesticides and fungicides are necessary to use while cultivating hemp [3]. According to the literary sources, hemp improves soil structure, suppress weeds and soil becomes free from diseases and pests $[3,4]$.

Nitrogen is quantitatively the most significant element for plant growth and development [5]. Nitrogen participates in cell growth and metabolism $[6,7]$, and it is considered to limit yield [7]. Nitrogen is the element that is most widely used in agriculture [8].

While breeding agricultural crops, it is important to take care of conservation and application of natural resources. That is why before starting the introduction of any new crop into national agriculture, it is necessary to develop scientifically reasoned recommendations according to existing soil and climatic conditions. Hemp fertilization methodology badly varies in different countries. For example, in Canada quoted nitrogen doses range from 60 to $90 \mathrm{~kg} \mathrm{ha}^{-1}$ [9], while in EU countries doses vary between $80-160 \mathrm{~kg} \mathrm{ha}^{-1}$, depending on soil composition [10]. Recommendations for hemp breeding developed in EU are not considered to be suitable for Latvian climatic and soil conditions.

In the literary sources data about the importance of additional fertilizer in hemp is found [11]. To avoid loss of nitrogen, it is recommended to divide nitrogen fertilizer into several portions [12].

To provide local hemp breeders with essential information about hemp cultivation, in Latgale Agricultural science centre (LASC) experiments were arranged. Researchers determine hemp varieties that suit Latvian conditions and agrotechnical parameters of hemp breeding technology, and also develop environmentally friendly fertilization technologies. There is a lack of fundamental research on nitrogen impact on hemp physiological processes including photosynthesis as a major yield-forming factor. 
The aim of the present study was to evaluate nitrogen fertilizer impact on photosynthesis and yield of hemp. The main object of the investigation - hemp cultivar of Latvian origin 'Pūrinii', grown since 1936 in Piksāru district of Rūjiena region.

We consider using modern non-destructive methods for indication of nitrogen supply efficiency is a perspective trend for agriculture. Because photosynthetic efficiency is linked to plant productivity, we consider measuring different photosynthetic parameters during vegetation period can provide significant information about plant physiological condition and prevent plant stress caused by excessive/insufficient fertilizer supply.

\section{Materials and methods \\ Field experiment}

Growth conditions / Experimental treatment

Field experiment was performed in LASC. The agricultural characteristics of soil are summarized in table 1.

Agricultural characteristics of soil in field experiments

\begin{tabular}{|c|c|c|c|c|c|c|}
\hline Year & $\begin{array}{c}\text { Organic } \\
\text { matter } \\
\text { content }(\%)\end{array}$ & pH & $\begin{array}{c}\text { Phosphorus } \\
\text { content } \mathbf{P}_{2} \mathbf{O}_{2} \\
\left(\mathbf{m g ~ k g}^{-1}\right)\end{array}$ & $\begin{array}{l}\text { Potassium } \\
\text { content } \mathrm{K}_{2} \mathrm{O} \\
\left(\mathrm{mg} \mathrm{kg}^{-1}\right)\end{array}$ & $\begin{array}{c}\text { Preliminary } \\
\text { plant }\end{array}$ & $\begin{array}{l}\text { Complex fertilizer NPK, } \\
\text { applied after first soil } \\
\text { cultivation }\left(\mathrm{kg} \mathrm{ha}^{-1}\right)\end{array}$ \\
\hline 2008 & 3,8 & 7,3 & 83 & 65 & Spring rape & $6: 26: 30-300$ \\
\hline 2009 & 4,5 & 7,3 & 134 & 122 & Spring rape & $18: 9: 9-330$ \\
\hline 2010 & 6,5 & 7,0 & 145 & 118 & Bare fallow & $18: 9: 9-350$ \\
\hline
\end{tabular}

Field soil - sod podzolic sandy-loamy soil. Before the arrangement of the experiment field was drained, relief equalized. Experiments were organized by randomized block method. Isolation between variants and isolation between duplications was $0,5 \mathrm{~m}$.

\section{Meteorological conditions}

Data of meteorological conditions during experiment provided by Adcon meteostation, connected to PlantPlus computer program.

Overall, according to the air temperature data (fig. 1), 2008, 2009 and 2010 vegetation months were warmer, than generally in LASC. Average air temperature in 2008, 2009 and 2010 was $12,9{ }^{\circ} \mathrm{C}, 12,8{ }^{\circ} \mathrm{C}$ and $14,3{ }^{\circ} \mathrm{C}$ respectively, while long-term average result is $12,2{ }^{\circ} \mathrm{C}$.

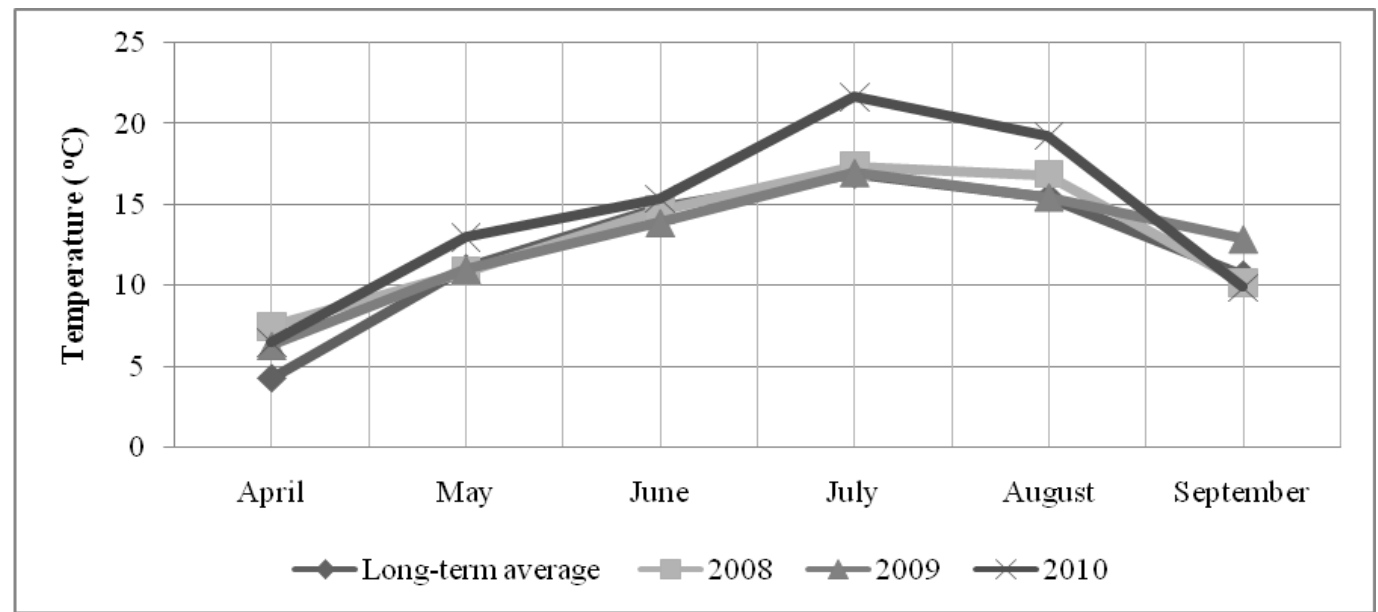

Fig. 1. Air temperature during 2008 - 2010 vegetation months in LASC

Total air temperature values in 2008, 2009 and 2010 were $77,6{ }^{\circ} \mathrm{C}, 76,6{ }^{\circ} \mathrm{C}$ and $85,8{ }^{\circ} \mathrm{C}$ respectively, comparing to the long-term average value equal to $73,3{ }^{\circ} \mathrm{C}$.

According to the rainfall data, we must conclude that 2008, 2009 and 2010 were dryer years, comparing to long-term average data (fig. 2). 


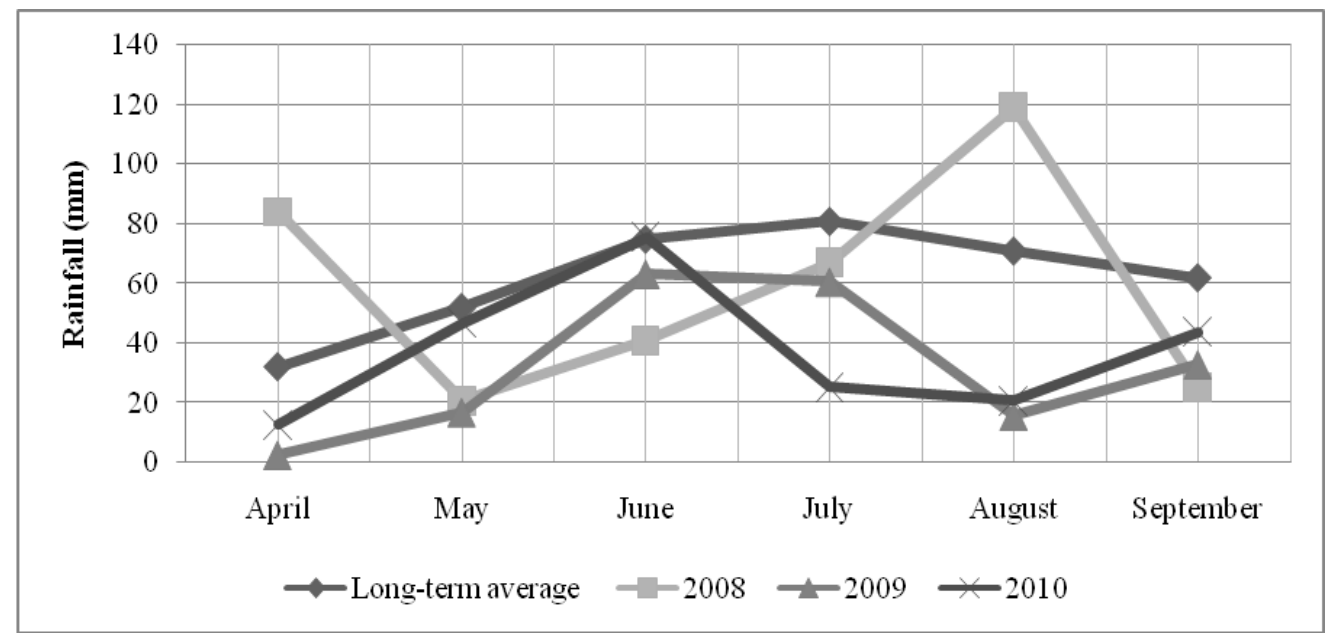

Fig. 2. Rainfall during 2008 - 2010 vegetation months in LASC

Total rainfall, comparing to long-term average $373 \mathrm{~mm}$, in 2008 was per 4,3\% lower, in 2009 - per 48,7 \% lower, and in 2010 - per 39,9\% lower.

\section{Unsaturated fatty acid composition of seed oil}

Unsaturated fatty acid composition was determined for hempseed oil using gas chromatography equipment (SHIMADZU GC-2010 and YL6100GC (Young Lin Instrument)).

\section{Growth conditions/ Experimental treatment}

\section{Laboratory experiment}

Laboratory experiment performed in the University of Latvia, Plant Physiology department in 2009. Seeds sown into vegetation containers with total volume $0,59 \mathrm{~L}$, filled with peat substratum KANO $\left(\mathrm{pH}(\mathrm{KCl}) 5,5-7,0, \mathrm{~N}\right.$ content $180 \mathrm{mg} \mathrm{l}^{-1}, \mathrm{~K}_{2} 0$ content $400 \mathrm{mg} \mathrm{l}^{-1}, \mathrm{P}_{2} \mathrm{O}_{5}$ content $\left.245 \mathrm{mg} \mathrm{l}^{-1}\right)$. For plant fertilization $10 \%$ ammonium nitrate $\left(\mathrm{NH}_{4} \mathrm{NO}_{3}\right)$ solution was prepared. In experiment three nitrogen fertilizer doses were used: $\mathrm{N}_{0}-$ control, $\mathrm{N}_{60}-60 \mathrm{~kg}$ $\mathrm{ha}^{-1}, \mathrm{~N}_{100}-100 \mathrm{~kg} \mathrm{ha}^{-1}$. All plants were divided into three variants with first fertilization time. Measurements of total chlorophyll content and chlorophyll $a$ fluorescence were performed four times. During the first measuring time (I) majority of plants were in vegetative stage and had at least three pairs of leaves. All plants were in vegetative stage during the second measuring time (II), part of plants showed change of phyllotaxis. While performing measurements in the third time (III), plant transition to flowering stage was detected. During the fourth measuring time (IV) all plants were in intensive flowering stage.

\section{Total chlorophyll content}

Chlorophyll content was determined using non-destructive Minolta SPAD-502 chlorophyll meter. At least 30 readings from a leaf were used to get one final average reading. In each variant final average readings of 30 leaves were analyzed (on average two leaves from 15 plants). The mean of the measurement was calculated using the internal function of the chlorophyll meter.

\section{Chlorophyll $a$ fluorescence}

Chlorophyll $a$ fluorescence was measured using non-destructive Handy PEA portable fluorescence measurement system (Hansatech instruments). Leaves were dark-adapted with leaf clips for 25 minutes before measurement. Measurements were repeated for all variants (20 measurements for each variant). The mean of the measurement was calculated using $M S$ Excel program. 


\section{Field experiment}

\section{Results and discussion}

According to the literary sources, fiber varieties of hemp demand higher rainfall levels then oil varieties [13]. Interestingly that in 2008, when rainfall amount was higher, average fiber content in hemp stems was lower, then in dryer 2009 and 2010 (fig. 3).

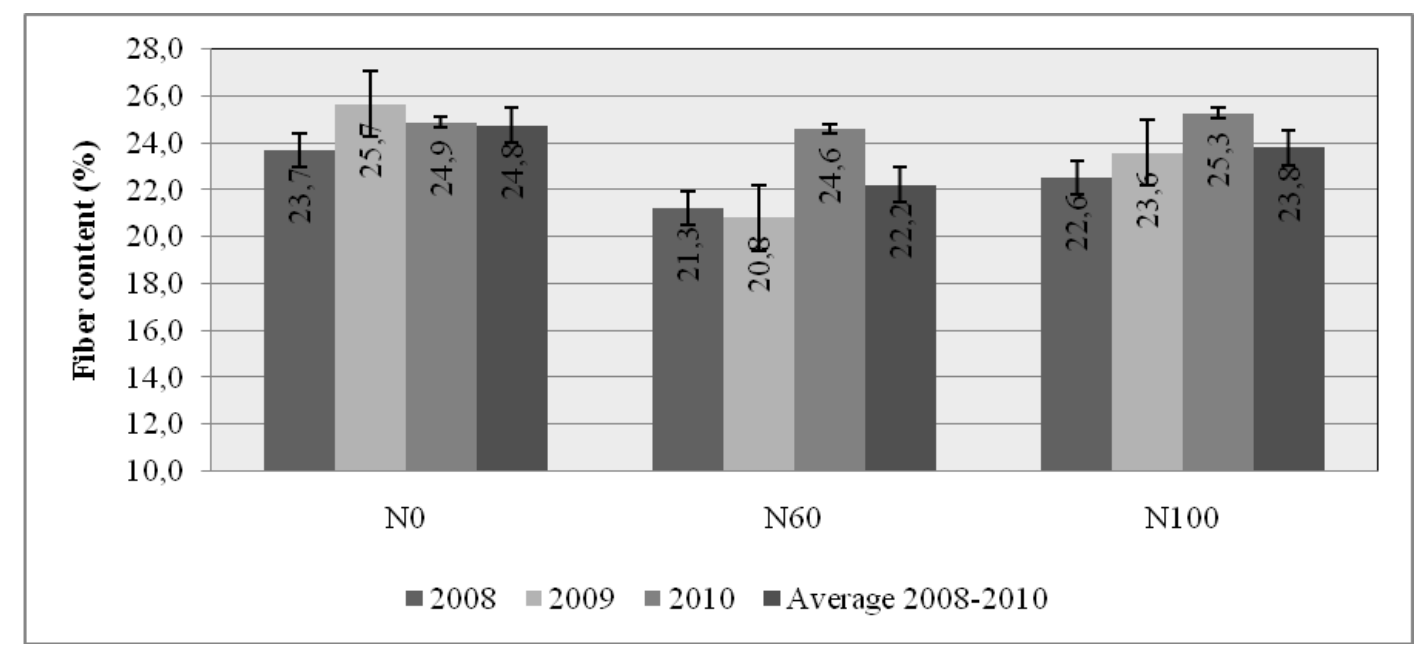

Fig. 3. Fiber content (\%) in hemp stems under different nitrogen fertilizer supply

It is significant that in stems of unfertilized control plants average fiber content was up to 7,8 $\%$ higher than in fertilized plants. It could be explained by the fact that received nitrogen in fertilized plants promotes usage of photosynthetic assimilates in amino acid biosynthesis. As it is known, biosynthesis of carbohydrates competes with biosynthesis of amino acids for distribution of photosynthetic assimilates [14], therefore schlerenhyma cells, that form fibers, are produced in smaller amounts. Probably, while cultivating hemp only for fiber production, use of nitrogen fertilizer should be reduced.

According to the literary sources, in Latvian conditions hemp can produce from half of a ton up to one ton seeds from one hectare [11]. Substantially, that seed yield of local hemp variety 'Pūrinii' showed higher results (fig. 4.). For example, in $2009 \mathrm{~N}_{100}$ variant hemp plants produced more than 2,5 tons seeds from hectare.

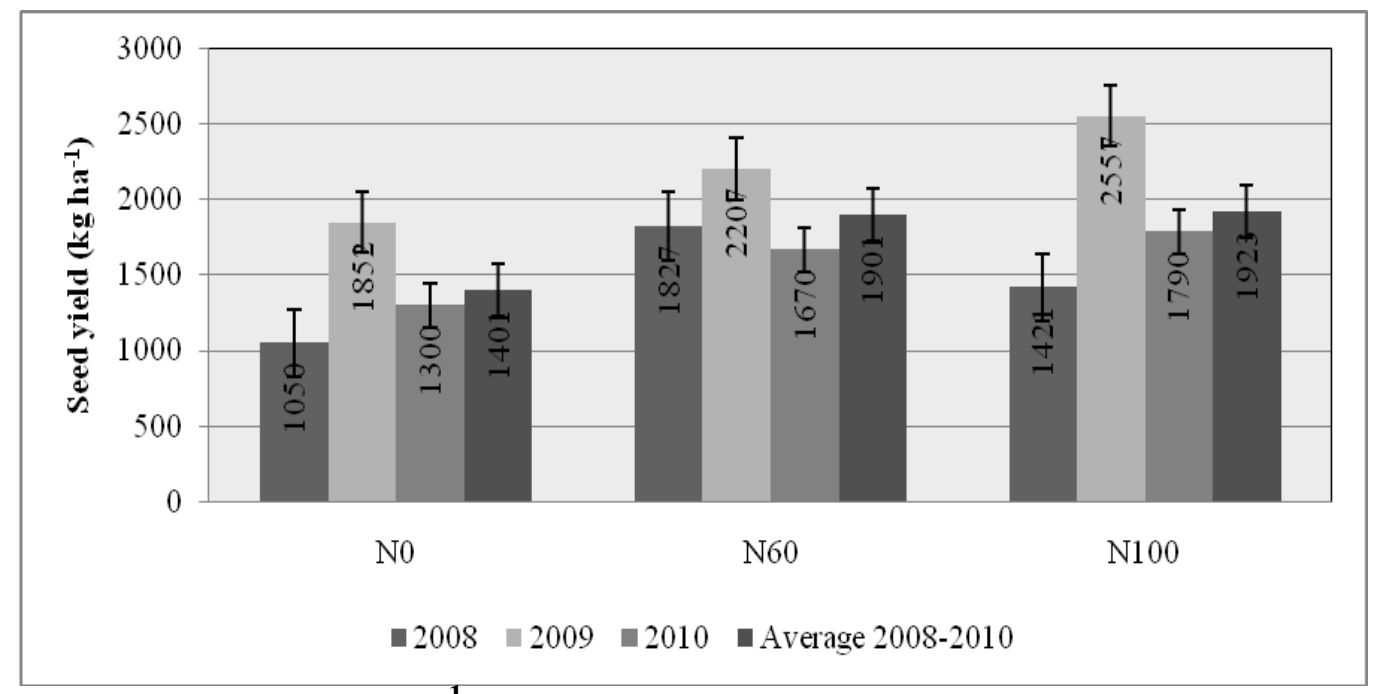

Fig. 4. Seed yield $\left(\mathrm{kg} \mathrm{ha}^{-1}\right)$ of hemp under different nitrogen fertilizer supply

We should mention that in 2008 the highest seed yield was in $\mathrm{N}_{60}$ variant, while hemp seed yield in dryer conditions of 2009 increased both in fertilized and unfertilized variant plants. In 2010 fertilized plants produced 28,5\% $\left(\mathrm{N}_{60}\right)$ and 37,7\% $\left(\mathrm{N}_{100}\right)$ higher seed yield, than 
unfertilized plants.Comparison of average seed yield results showed that average seed yield of fertilized plant for $36,5 \%$ exceeded seed yield of unfertilized plants.

In 2008 the highest seed mass was in $\mathrm{N}_{60}$ variant, in 2009 - in $\mathrm{N}_{0}$ and $\mathrm{N}_{100}$, but in 2010 the significant difference between variants has not been detected (fig. 5.).

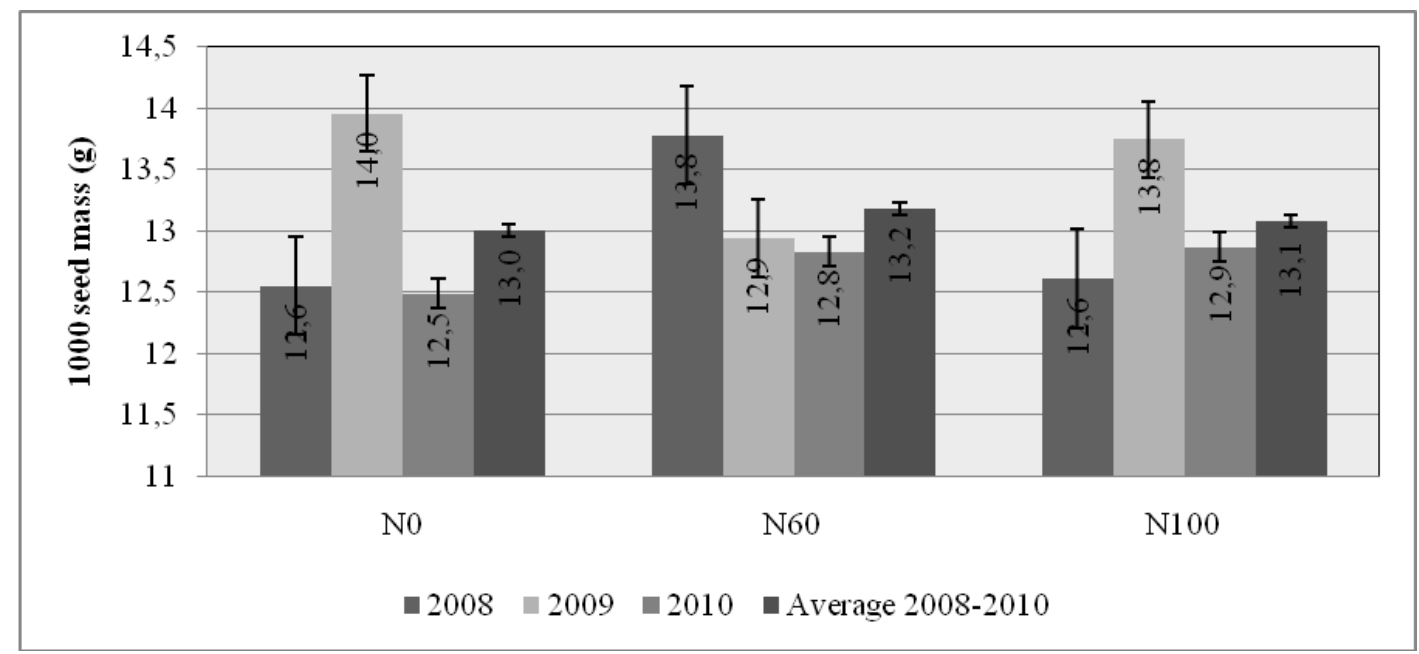

Fig. 5. 1000 seed mass (g) of hemp under different nitrogen fertilizer supply

From average values we can conclude that seed mass was not materially influenced by fertilizer. Explicit impact on seed mass was detected for moisture conditions. In 2008, when total rainfall was only per $4,3 \%$ lower than long-term average, $\mathrm{N}_{60}$ plant seeds were in average per $9,5 \%$ heavier than $\mathrm{N}_{0}$ and $\mathrm{N}_{100}$ variant plant seeds. In relatively dryer 2009 difference between seed mass of $\mathrm{N}_{0}$ and $\mathrm{N}_{100}$ was not significant, and seed mass of $\mathrm{N}_{60}$ plants was about $8 \%$ lower, than in non-fertilized $\mathrm{N}_{o}$ plants. Therefore we must conclude that according to the seed mass results, additional nitrogen fertilizer doses should be applied, following the climatic conditions. In the vegetation period, guided with higher rainfall levels, $60 \mathrm{~kg}$ of additional nitrogen fertilizer per hectare can be considered as an optimal amount.

Determination of unsaturated fatty acid composition of cold pressed hempseed oil proved that it's very valuable because of the presence of linoleic, $\alpha$-linolenic, $\gamma$-linolenic, oleic, eicosenoic and erucic fatty acids (fig. 6.)

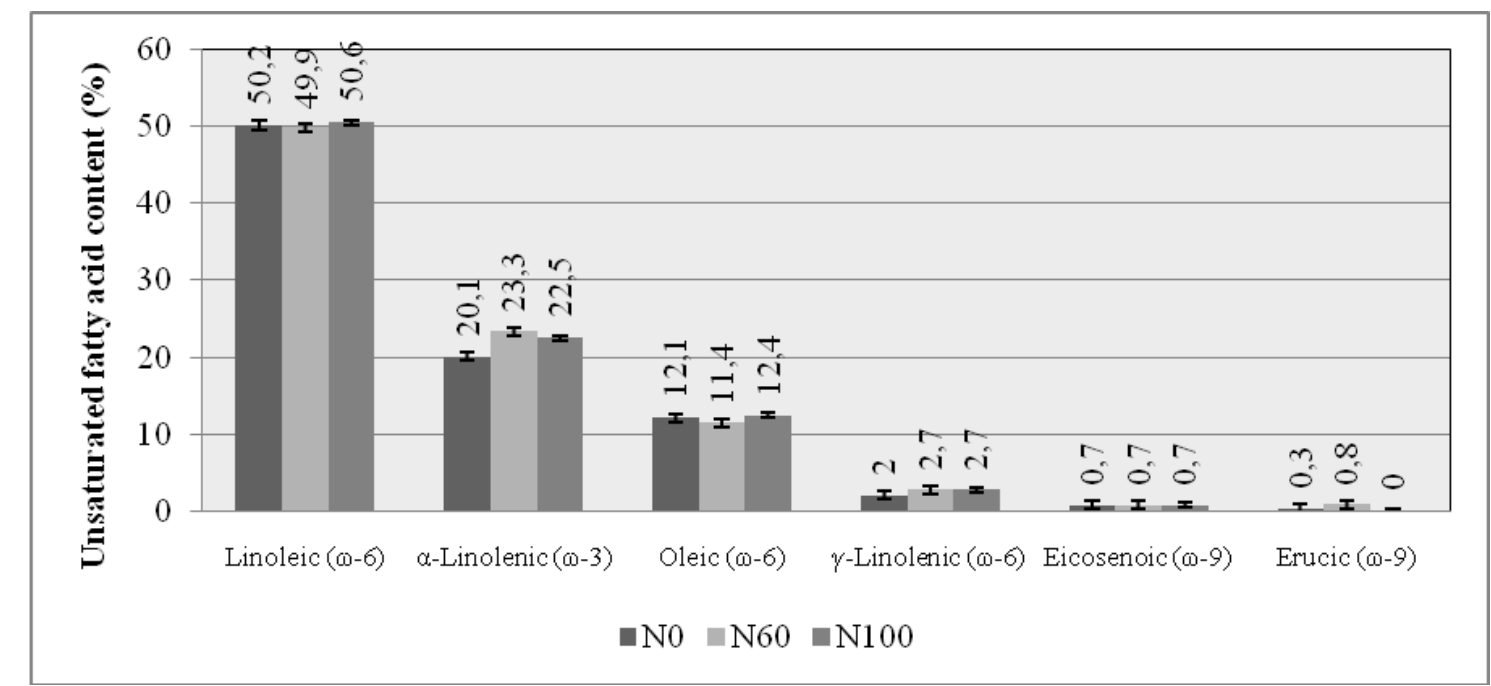

Fig. 6. Unsaturated fatty acid content (\%) in cold pressed hempseed oil, depending on different nitrogen fertilizer supply 
According to the literary sources nitrogen can negatively affect fatty acid composition of oil culture seeds [15]. In the current investigation hemp seed oil composition was not negatively affected by nitrogen fertilizer.

\section{Laboratory experiment}

During the current investigation we ascertained that chlorophyllmetry is a fast and nondestructive method, which can be repeated during ontogenesis, so we can join other authors' statement that this method is very useful [16, 17, 18, 19]. According to the dynamics of chlorophyll content changes we can conclude that both in fertilized and non-fertilized plants chlorophyll content gradually increased during ontogenesis (fig. 7.).

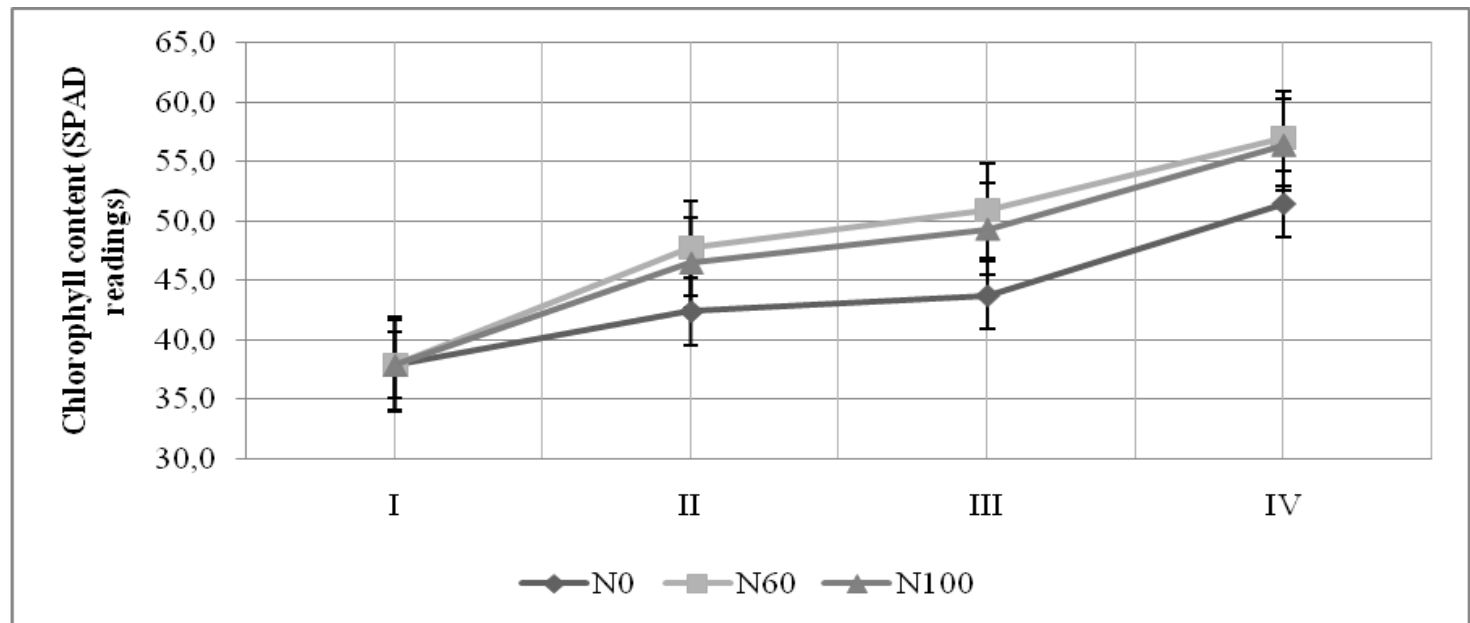

Fig. 7. Chlorophyll content changes in hemp leaves under different nitrogen fertilizer supply, determined with chlorophyll meter Minolta SPAD-502

Investigations of different cultivated plants, that were held out in recent years [17, 8, 20] showed SPAD reading correlation with absolute chlorophyll values, so these readings can be considered as reliable. Moreover, according to the opinion mentioned in literature, use of chlorophyll meter in laboratory conditions is especially effective [21]. Wherewith in current experiment chlorophyll content was determined in laboratory conditions, we can forecast that results are reliable and influence of the outward factors was minimal.

Schlemmer and others [8] write that photosynthetic potential is directly proportional to the chlorophyll content in plant tissues. Respectively, our data of chlorophyll content in hemp leaves describes photosynthetic potential of differently fertilized plants. Many authors recommend chlorophyll meter for determination of the nitrogen status and efficiency of nitrogen supply in plants $[19,22,23,21,24]$. It is necessary to mention, that starting with the first fertilization and until the last fertilization, higher SPAD reading values were established in $\mathrm{N}_{60}$ variant plants. Therefore, according to the data of chlorophyll content in hemp leaves we can forecast, that in $\mathrm{N}_{60}$ variant plants photosynthetic potential will be higher than in control and $\mathrm{N}_{100}$ variant plants, and that nitrogen fertilizer dose equal to $60 \mathrm{~kg} \mathrm{ha}^{-1}$ is most efficient.

In addition to chlorophyll content different chlorophyll $a$ fluorescence parameters were observed. PI (Performance Index) is considered to be one of the most valuable parameters that diversely describes common vitality of plant. Parameter combines several photosynthetic parameters such as the density of active reaction centers, efficiency of received energy transport in ETC and electron flux rate [25]. As nitrogen supply improves quantity of FSII reaction center and electron transport rate [7], but nitrogen deficiency decreases photosynthetic chain reaction rate [6], PI parameter changes can characterize efficiency of nitrogen supply.

The highest performance index was established in $\mathrm{N}_{100}$ treatment plants (fig. 8.). 


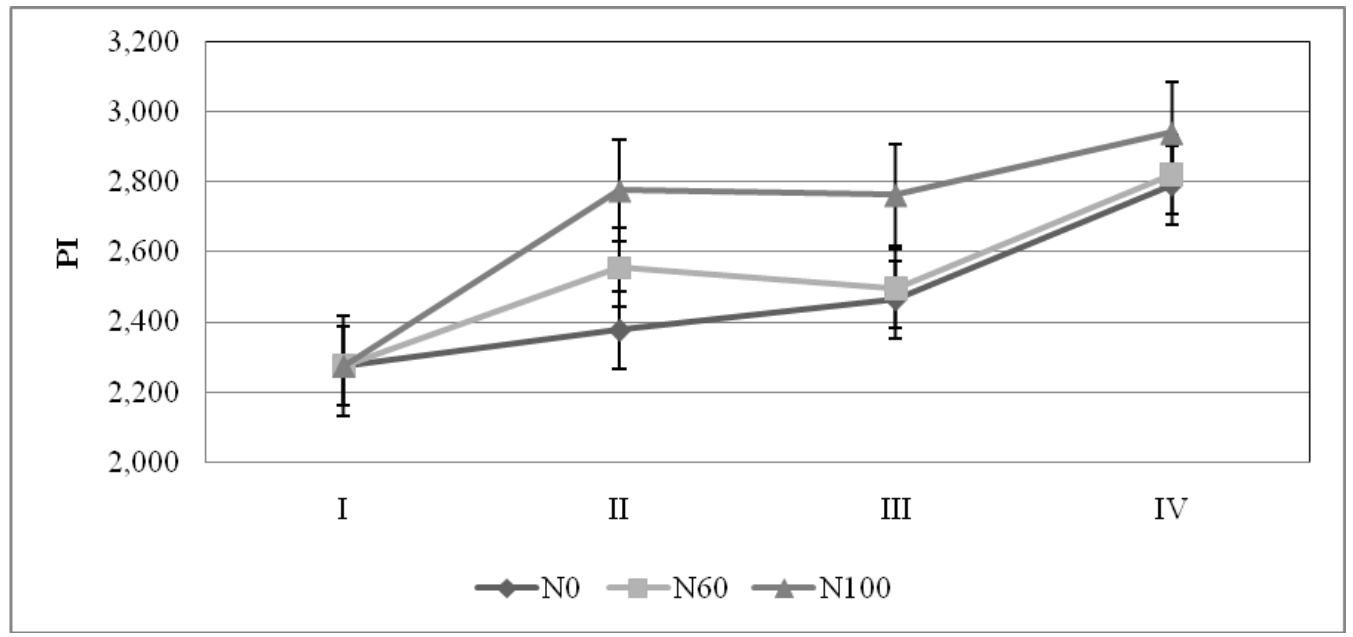

Fig. 8. Chlorophyll a PI changes in hemp leaves under different nitrogen fertilizer supply, determined with Handy PEA

During the whole investigation PI values in $\mathrm{N}_{100}$ exceeded PI values both in $\mathrm{N}_{0}$ and $\mathrm{N}_{60}$ variants. But we must mention that statistically significant difference between PI ratios of $\mathrm{N}_{100}$ and $\mathrm{N}_{0}$ was detected only when plants were changing from vegetative to flowering stage (II and III). We can conclude, that in spite of lack or presence of additional nitrogen fertilizer, performance index of hemp gradually increased during ontogenesis.

Nevertheless hemp plants showed higher vitality (performance index) under the highest additional nitrogen fertilizer supply, the analysis of the other photosynthetic parameters must be taken into consideration.

One of the rarely analyzed parameters is $\mathrm{F}_{\mathrm{v}} / \mathrm{F}_{\mathrm{o}}$ - parameter that describes activity of FSII. Respectively, higher $\mathrm{F}_{\mathrm{v}} / \mathrm{F}_{\mathrm{o}}$ values indicate more active FSII [26]. During the current investigation values of $\mathrm{F}_{\mathrm{v}} / \mathrm{F}_{\mathrm{o}}$ parameter fluctuated (fig. 9.).

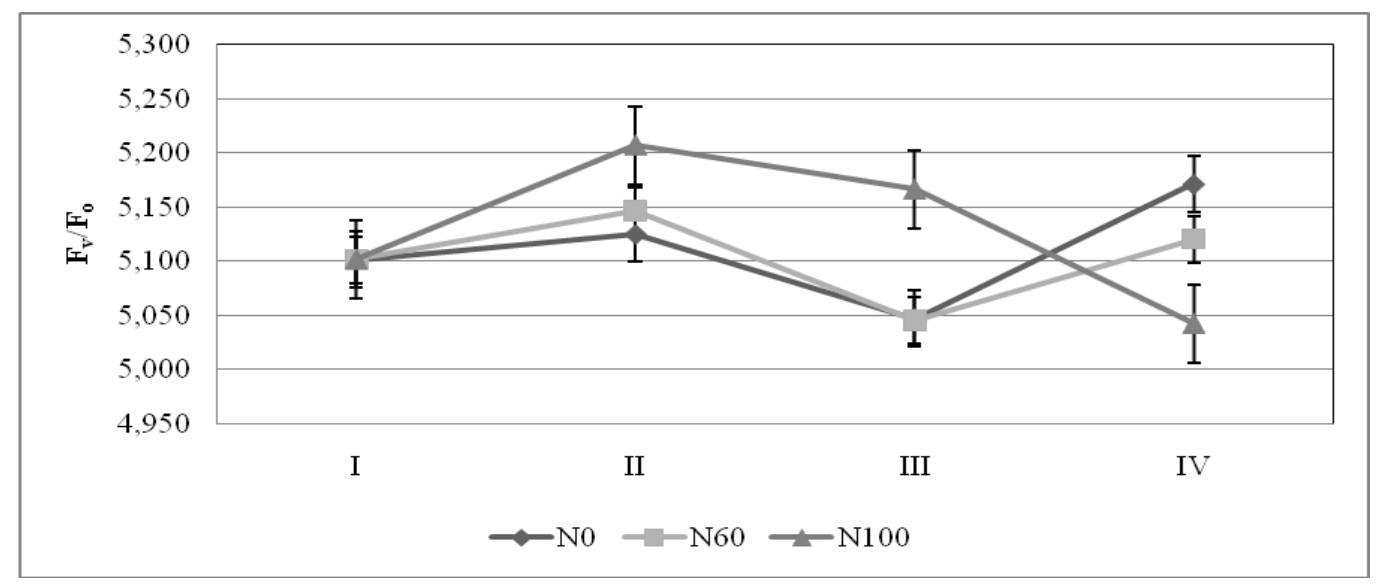

Fig. 9. Chlorophyll a $\mathbf{F}_{\mathbf{v}} / \mathbf{F}_{\mathbf{o}}$ changes in hemp leaves under different nitrogen fertilizer supply, determined with Handy PEA

In the beginning of the experiment all variant plants showed an increase of FSII activity, and the highest value of $\mathrm{F}_{\mathrm{v}} / \mathrm{F}_{\mathrm{o}}$ was detected in $\mathrm{N}_{100}$ plants. During the stage of generic organ development and in the beginning of flowering stage (II - III) in all variant plants decrease of FSII activity was observed, however in $\mathrm{N}_{100}$ variant plants FSII was still most active. During the flowering phase (III - IV) a significant decrease of FSII activity in $\mathrm{N}_{100}$ variant plants was observed, in contrast to $\mathrm{N}_{0}$ and $\mathrm{N}_{60}$ variant plants, where a rapid increase of FSII activity was observed. It can be explained with $\mathrm{N}_{100}$ plant reaction on final additional fertilizer, that 
probably negatively influenced plant photosynthetic apparatus. Changes of FSII activity in $\mathrm{N}_{0}$ and $\mathrm{N}_{60}$ plants can be linked to the plant developmental changes.

$\mathrm{F}_{\mathrm{v}} / \mathrm{F}_{\mathrm{m}}$ is the most frequently referred in literature chlorophyll $a$ fluorescence parameter. $\mathrm{F}_{\mathrm{v}} / \mathrm{F}_{\mathrm{m}}$ is considered to be "stress indicator" [27] and its changes can indicate a negative/positive impact of different fertilizer doses on plants. Hemp is C3 plant [28], and according to the literature data typical $\mathrm{F}_{\mathrm{v}} / \mathrm{F}_{\mathrm{m}}$ parameter value for dark-adapted non-stressed $\mathrm{C} 3$ plants is 0,800 - 0,830 [29]. In experiments about hemp tolerance against cadmium impact $F_{v} / F_{m}$ parameter values varied between 0,800 and 0,810 [30], other authors mention lower $\mathrm{F}_{\mathrm{v}} / \mathrm{F}_{\mathrm{m}}$ parameter values - from 0,660 to 0,810 [31]. In the current investigation $F_{v} / F_{m}$ parameter values substantially exceeded mentioned values (fig. 10.), and possibly these changes were caused by additional fertilizing with nitrogen.

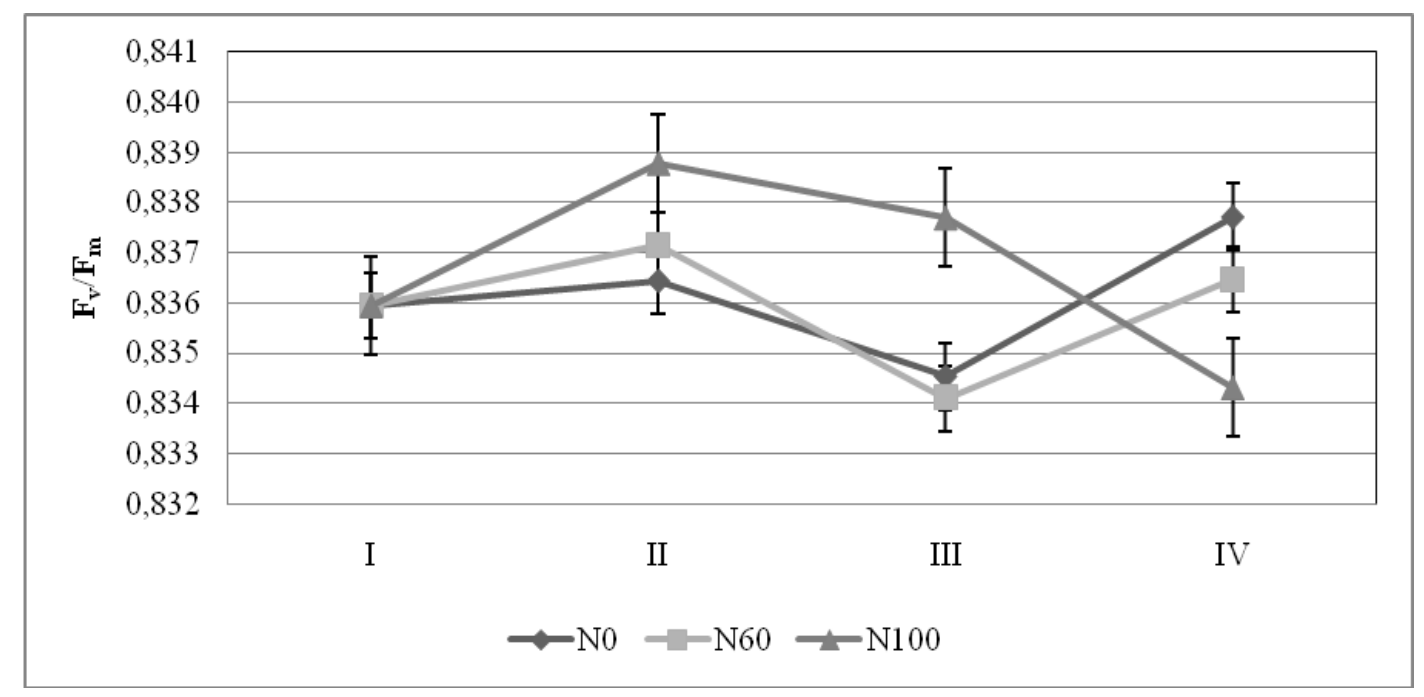

Fig. 10. Chlorophyll a $\mathbf{F}_{\mathrm{v}} / \mathbf{F}_{\mathbf{m}}$ changes in hemp leaves under different nitrogen fertilizer supply, determined with Handy PEA

According to the literary sources, under disadvantaged environmental conditions that cause oxidative stress in plants, $F_{v} / F_{m}$ value decrease is expected [31]. For example, nitrogen deficiency caused $F_{v} / F_{m}$ parameter value decrease in spinach [32]. Previous investigations showed that $F_{v} / F_{m}$ parameter values increased in plants, fertilized with nitrogen [33]. During our investigation $\mathrm{F}_{\mathrm{v}} / \mathrm{F}_{\mathrm{m}}$ parameter value fluctuations were observed both in fertilized and nonfertilized plants. Initially, in all variant plants similar value fluctuations were established (I III), with the highest parameter values in $\mathrm{N}_{100}$ variant plants. However final measurements (IV) showed that $\mathrm{N}_{100}$ variant plant $\mathrm{F}_{\mathrm{v}} / \mathrm{F}_{\mathrm{m}}$ values continued to decrease, while $\mathrm{N}_{0}$ and $\mathrm{N}_{60}$ variant plant $\mathrm{F}_{\mathrm{v}} / \mathrm{F}_{\mathrm{m}}$ values increased. Between the control and $\mathrm{N}_{100}$ variant plant $\mathrm{F}_{\mathrm{v}} / \mathrm{F}_{\mathrm{m}}$ parameter values statistically substantial differences persisted during the experiment.

There are references in literature that excessive nitrogen fertilizer supply can cause stress that resembles nitrogen deficiency features [7]. Therefore it is logical to assume that $F_{v} / F_{m}$ value decrease in $\mathrm{N}_{100}$ variant plants in the beginning of current investigation, and increase in $\mathrm{N}_{0}$ and $\mathrm{N}_{60}$ variant plants in the end of investigation (fig. 10) indicate improvement of the plant condition. 


\section{Conclusions}

After the evaluation of the nitrogen fertilizer impact on photosynthesis and yield of hemp, we must deduce that recommendations in hemp fertilization developed in EU are not suitable for Latvian conditions. According to the results of the current investigation, several conclusions were made.

According to the chlorophyll content the most efficient additional nitrogen fertilizer dose for hemp cultivar of Latvian origin 'Pūrini' is $60 \mathrm{~kg} \mathrm{ha}^{-1}$. Although the highest performance index was determined in $\mathrm{N}_{100}$ variant plants, evaluating of all chlorophyll $a$ fluorescence parameters showed that physiological efficiency of $\mathrm{N}_{60}$ variant plants was higher.

In field conditions, seed yield of fertilized plants in average per 36,5\% exceeded control variant plant seed yield. In average, a significant difference between seed yield of $\mathrm{N}_{60}$ and $\mathrm{N}_{100}$ variants has not been observed. Nitrogen fertilizer negatively affected fiber content in hemp stems, therefore while cultivating hemp only for fiber production, usage of nitrogen fertilizer should be reduced. According to the seed mass results, additional nitrogen fertilizer doses should be applied following the climatic conditions. In the vegetation period guided with higher rainfall levels, $60 \mathrm{~kg}$ of additional nitrogen fertilizer per hectare can be considered as the optimal amount. In the current investigation hemp seed oil composition was not negatively affected by nitrogen fertilizer.

To avoid excessive nitrogen fertilizer usage, its negative impact on plant physiology and yield losses, we consider nitrogen fertilizer $60 \mathrm{~kg} \mathrm{ha}^{-1}$ as additional fertilizer is optimal for hemp cultivar of Latvian origin 'Pūriņi'. Current hemp cultivar is potentially valuable and perspective hemp cultivar that in local conditions can produce both fiber and significant seed yield, containing oil with high nutritional and pharmaceutical value.

\section{References}

1. Bagci E., Bruehl L., Aitzetmuller K., Altan Y. 2003. A chemotaxonomic approach to the fatty acid and tocochromanol content of Cannabis sativa L. (Cannabaceae). - Turkish Journal of Botany 27:141-147

2. Anwar F., Latif S., Ashraf M. 2006. Analytical characterization of hemp (Cannabis sativa) seed oil from different agro-ecological zones of Pakistan. - Journal of the American Oil Chemists' Society (JAOCS) 83:323-329

3. Bismarck A., Mishra S., Lampke T. 2005. Plant fibers as reinforcement for Green Composites. In: Mohanty A.K., Misra M., Drzal L.T. (Eds) Natural fibers, biopolymers, and biocomposites. CRC Press, Taylor and Francis Group, pp:39-108

4. Bavec F., Bavec M. 2007. Organic production and use of alternative crops. CRC Press, Taylor and Francis Group, $241 \mathrm{pp}$

5. Girard J.E. 2009. Principles of environmental chemistry, Second edition. Jones \& Bartlett Publishers, 687 pp

6. Xu Z.Z., Zhou G.S. 2006. Nitrogen metabolism and photosynthesis in Leymus chinensis in response to longterm soil drought. - Journal of Plant Growth Regulation 25:252-266

7. Zhou X.J., Liang Y., Chen H., Shen S.H., Jing Y.X. 2006. Effects of rhizobia inoculation and nitrogen fertilization on photosynthetic physiology of soybean. - Photosynthetica 44:530-535

8. Schlemmer M.R., Francis D.D., Shanahan J.F., Schepers J.S. 2005. Remotely measuring chlorophyll content in corn leaves with differing nitrogen levels and realtive water content. - Agronomy Journal 97:106-112

9. Smith-Heisters S. 2008. Environmental costs of hemp prohibition in the United States. - Journal of Industrial Hemp 13:157-170

10. Anonymous. 2004. IENICA (Interactive European Network for Industrial Crops and their Applications) Agronomy Guide. Generic guidelines on the agronomy of selected industrial crops, pp:4-5

11. Driķis J. 2004. Kaṇepes : Ruža A., Adamovičs A., Bankina B., Bērziņš A., Driķis J., Kārkliņ̌̌ A., Kreišmane D., Kreita D., Turka I., Ruža E. 2004. Augkopība. Jelgava: Latvijas Lauksaimniecības Universitāte, 374 lpp

12. Mediavilla V., Jonquera M., Schmid-Slembrouck I., Soldati A. 1998. Decimal code for growth stages of hemp (Cannabis sativa L.). - Journal of the International Hemp Association 5:65,68-74

13. Elzebroek T., Wind K. 2008. Guide to cultivated plants. CAB International, Wallingford, UK, 540 pp

14. Foyer C.H., Ferrario-Mery S., Noctor G. 2001. Interactions between carbon and nitrogen metabolism. In: Lea P.J., Morot-Gaudry J.F. (Eds) Plant nitrogen. Springer, pp:237-254

15. Egesel C.O., Gul M.K., Kahriman F., Ozer I., Turk F. 2008. The effect of nitrogen fertilization on tocopherols in rapeseed genotypes. - European Food Research and Technology 227:871-880 


\section{Mal̦ceva M., Stramkale V., Vikmane M. PHYSIOLOGICAL ASPECTS OF NITROGEN FERTILIZER IMPACT ON LATVIAN ORIGIN CANNABIS SATIVA L.}

16. Richardson D.A., Duigan P.S., Berlyn P.G. 2002. An evaluation of noninvasive methods to estimate foliar chlorophyll content. - New Phytologist 153:185-194

17. Netto A.T., Campostrini E., de Oliveira J.G., Bressan-Smith R.E. 2005. Photosynthetic pigments, nitrogen, chlorophyll $a$ fluorescence and SPAD-502 readings in coffee leaves. - Scientia Horticulturae 104:199-209

18. Neufeld H.S., Chappelka A.H., Somers G.L., Burkey K.O., Davison A.W., Finkelstein P.L. 2006. Visible foliar injury caused by ozone alters the relationship between SPAD meter readings and chlorophyll concentrations in cutleaf coneflower. - Photosynthesis Research 87:281-286

19. Olivier M., Goffart J.P., Ledent J.F. 2006. Threshold value for chlorophyll meter as decision tool for nitrogen management of potato. - Agronomy Journal 98:496-506

20. Samsone I., Andersone U., Vikmane M., Ievina B., Pakarna G., Ievinsh G. 2007. Nondestructive methods in plant biology: an accurate measurement of chlorophyll content by a chlorophyll meter. - Acta Universitatis Latviensis 723:145-154

21. Zhang J., Blackmer A.M., Ellsworth J.W., Koehler K.J. 2008. Sensitivity of chlorophyll meters for diagnosing nitrogen deficiencies of corn in production agriculture. - Agronomy Journal 100:543-550

22. Scharf P.C., Brouder S.M., Hoeft R.G. 2006. Chlorophyll meter reading can predict nitrogen need and yield response of corn in the North-Central USA. - Agronomy Journal 98:655-665

23. Esfahani M., Abbasi H.R.A., Rabiei B., Kavousi M. 2008. Improvement of nitrogen management in rice paddy fields using chlorophyll meter (SPAD). - Paddy And Water Environment 6:181-188

24. Hassan M.S., Khair A., Haque M.M., Azad A.K., Hamid A. 2009. Genotypic variation in traditional rice varieties for chlorophyll content, SPAD value and nitrogen use efficiency. - Bangladesh Journal of Agricultural Research 34:505-515

25. Pinior A., Grunewaldt-Stocker G., Alten H., Strasser R.J. 2005. Mycorrhizal impact on drought stress tolerance of rose plants probed by chlorophyll $a$ fluorescence, proline content and visual scoring. Mycorrhiza 15:596-605

26. Skorzynska-Polit E., Baszynski T. 2000. Does $\mathrm{Cd}^{2+}$ use $\mathrm{Ca}^{2+}$ channels to penetrate into chloroplasts? - a preliminary study. - Acta Physiologiae Plantarum 22:171-178

27. Maxwell K., Johnson G.N. 2000. Chlorophyll fluorescence - a practical guide. - Journal of Experimental Botany 51:659-668

28. Wang R.Z. 2004. Photosynthetic pathways and life form type for native plant species from Hulunbeier Rangelands, Inner Mongolia, North China. - Photosynthetica 42:219-227

29. Bown H.E., Mason E.G., Clinton P.W., Watt M.S. 2009. Chlorophyll fluorescence responce of Pinus radiata clones to nitrogen and phosphorus supply. - Ciencia e Investigacion Agraria 36:451-464

30. Shi G.R., Cai Q.S., Liu Q.Q., Wu L. 2009. Salicylic acid-mediated alleviation of cadmium toxicity in hemp plants in relation to cadmium uptake, photosynthesis, and antioxidant enzymes. - Acta Physiologiae Plantarum 31:969-977

31. Linger P., Ostwald A., Haensler J. 2005. Cannabis sativa L. growing on heavy metal contaminated soil: growth, cadmium uptake and photosynthesis. - Biologia Plantarum 49:567-576

32. Verhoeven A.S., Demmig-Adams B., Adams W.W. 1997. Enhanced employment of the xanthophyll cycle and thermal energy dissipation in spinach exposed to high light and N stress. - Plant Physiology 113:817824

33. Otronen M., Rosenlund H.M. 2001. Morphological asymmetry and chlorophyll fluorescence in Scots pine (Pinus sylvestris): responses to variation in soil moisture, nutrients and defoliation. - Annales Botanici Fennici 38:285-294

Anotācija. Pētījuma mērķis bija novērtēt slāpekļa mēslojuma ietekmi uz fotosintēzi un ražu sējas kaņepēm, pielietojot modernas nedestruktīvas analīzes metodes. Pētījuma objekts - Latvijas izcelsmes sējas kaņepes 'Pūriņi'. Laboratorijas un lauka izmēgininājumi parādīja atšķirīgu slāpekl̦a devu dažādo ietekmi uz daudzējādiem parametriem. Slāpekla papildmēslojuma deva $60 \mathrm{~kg} \mathrm{ha}^{-1}$ ir visefekt̄̄vākā, novērtējot pēc hlorofila satura kaņepju lapās, ka arī pēc hlorofila a fluorescences parametru izmaiņām. Šķkiedras saturs augos slāpekļa mēslojuma ietekmē samazinās, tāpēc kaņepju audzēšanai tikai šķiedru ieguvei slāpekļa mēslojuma piegāde būtu jāsamazina. Attiecībā uz sēklu masu, papildmēslojums jāpiegādā, vadoties pēc klimatiskajiem apstākļiem. Veǵetācijas periodā ar lielāku nokrišn,u daudzumu slāpekla papildmēslojuma deva $60 \mathrm{~kg} \mathrm{ha}{ }^{-1}$ uzskatama par optimālo. Slāpekļa mēslojums mūsu pētījumā kaņepju el̦las kompozīciju negatīvi neietekmēja. Būtiskās atšksirības starp sēklu ražu $N_{60}$ un $N_{100}$ variantiem nenovēroja. Lai izvairītos no pārmērīgas slāpekla mēslojuma izmantošanas, to negatīvas ietekmes uz augu fiziologiju un ražas zudumiem, mēs uzskatam ka optimāla slāpekļa papildmēslojuma deva sējas kaņepēm 'Pūriņi' būtu $60 \mathrm{~kg} \mathrm{ha}^{-1}$.

Atslēgas vārdi: Cannabis sativa L., slāpekļa mēslojums, hlorofila saturs, hlorofila a fluorescence, raža. 